\title{
Components detected by headspace-solid phase microextraction in artisanal fresh goat's cheese smoked using dry prickly pear (Opuntia ficus indica)
}

\author{
María D. GUILLÉN*, María L. IBARGOITIA, Patricia SOPELANA, \\ Gemma PALENCIA \\ Tecnología de Alimentos, Facultad de Farmacia, Universidad del País Vasco, Paseo de la Universidad 7, \\ 01006 Vitoria, Spain
}

Received 18 July 2003 - Accepted 17 February 2004

Published online 7 June 2004

\begin{abstract}
The study of the headspace components of six different samples of hand-made fresh goat's cheese smoked with dry prickly pear (Opuntia ficus indica) smoke, protected by the Palmero Denomination of Origin, was carried out. These cheeses were manufactured by six different artisans from the Island of Palma. In spite of this cheese not being a ripened cheese, more than 330 components were detected, by means of solid phase microextraction using a polyacrylate fiber followed by gas chromatography/mass spectrometry. The cheese's exterior region was the richest in components because in addition to the characteristic cheese components it also contained all those adsorbed smoke components which had not reacted with the cheese components. The cheese's interior region was the poorest in components because only some of the smoke components had diffused towards the interior. Branched acids associated with goat's cheese flavor were not detected. In spite of the different smoking degree in the samples studied, homogeneous proportions of the main smoke phenolic derivatives were observed. Likewise, although differences in the absolute concentrations of acids were observed, fairly homogeneous proportions of the main acids were found. The absence of terpenes and sesquiterpenes and the presence of some nitrogen derivatives as well as of syringol derivatives in significant concentrations, together with characteristic proportions of phenolic derivatives, allow one to distinguish this Palmero cheese from that smoked with pine needles.
\end{abstract}

Opuntia ficus indica / smoked fresh goat cheese / volatile component / solid phase microextraction / gas chromatography-mass spectrometry

Résumé - Composés volatils des fromages de chèvre frais fumés à la fumée de figuier de Barbarie (Opuntia ficus indica) détectés par microextraction en phase solide. Six échantillons de fromages de chèvre frais artisanaux protégés par l'Appellation d'Origine de Palmero, fabriqués par six artisans de l'île de Palma et fumés avec de la fumée de figuier de Barbarie (Opuntia ficus indica), sont analysés pour leur teneur en composés volatils. Bien que ces fromages ne soient pas affinés, plus de 330 composés volatils sont détectés après microextraction en phase solide sur fibre polyacrylate couplée à de la chromatographie gaz/spectrométrie de masse. La zone externe du fromage est la plus riche en composés, car elle contient tous les composés de fumée adsorbés qui n'ont pas réagi avec les composés spécifiques au fromage, en plus des composés caractéristiques au fromage. La zone interne du fromage est la plus pauvre en composés, en effet seuls quelques composés de

\footnotetext{
* Corresponding author: knpgulod@vf.ehu.es
} 
fumée ont diffusé vers l'intérieur. Les acides gras ramifiés associés à la flaveur fromage de chèvre n'ont pas été détectés. Malgré leur degré variable de fumage, les échantillons étudiés contiennent des proportions analogues en dérivés phénoliques majeurs de la fumée. De même, des proportions voisines en acides gras majoritaires sont trouvées, malgré des différences dans les concentrations absolues en acides gras. L'absence de terpènes et sesquiterpènes, la présence de certains dérivés azotés, ainsi que des concentrations significatives de dérivés du syringol, et des proportions caractéristiques en dérivés phénoliques permettent de distinguer ce fromage de Palmero de ceux fumés avec des aiguilles de pin.

Opuntia ficus indica / fromage de chèvre frais fumé / composé volatil / microextraction en phase solide / chromatographie gaz-spectrométrie de masse

\section{INTRODUCTION}

Organoleptic properties are very important in food acceptation by consumers and especially in many cheeses often considered as delicacies. These properties are due to the food composition, and specifically food aroma is mostly determined by its headspace composition. For this reason the components of the headspace of many cheeses have been profusely studied using different techniques [1, 17-22, 25, 28]. However, in spite of the existence of many studies on those components responsible for the flavor of cheeses of very different origins and characteristics, the study of the headspace components of smoked cheeses has been rarely undertaken $[2,5,16]$, and the same can be said of fresh goat's cheese $[6,7,9,23,27,30]$.

In this paper the study of the volatile and less volatile components of the headspace of the fresh smoked artisanal goat's cheese protected by the Palmero Denomination of Origin is carried out. The cheese studied was smoked exclusively with dry prickly pear (Opuntia ficus indica) smoke, although other vegetable matters such as almond shells (Prunus dulcis), and the wood or needles of canary pine (Pinus canariensis) can be used. These cheeses are manufactured using milk from Palmera goats, by the milk producers themselves, only on the Island of Palma (The Canary Islands), following traditional methods passed down from generation to generation.
The study was accomplished by means of the extraction of the static headspace components using solid phase microextraction (SPME) followed by gas chromatography/mass spectrometry. The aim of this study is to establish the components of the headspace of this cheese, and to know the diffusion degree of the smoke components across the cheese matrix.

\section{MATERIALS AND METHODS}

\subsection{Samples}

Artisanal Palmero cheeses, manufactured from fresh untreated milk, by six different artisans of the Palma Island, named T1, T2, T3, T4, T5 and T6, were studied. All of them were smoked using dry prickly pear. The manufacture was carried out following the traditional methods [8]. From each cheese, three different parts were studied separately: the interior of the cheese; the exterior region; and a thin cross-section representative of the entire cheese, containing exterior and interior parts. The samples were chopped, and approximately $1 \mathrm{~g}$ of the chopped sample was weighed into a 4-mL amber vial Screw Top (acquired from Supelco, Bellefonte, PA, USA), sealed with a hole cap PTFE/silicone septum, and stored frozen until used for study. The day before the study each sample was transferred to the refrigerator for thawing. 


\subsection{Generation of the headspace and extraction of its components by SPME}

Vials containing $1 \mathrm{~g}$ of the cheese sample were introduced into a water bath maintained at $50{ }^{\circ} \mathrm{C}$. After a period of sample equilibration ( $15 \mathrm{~min})$ the fiber was inserted into the headspace of the sample and was maintained for $60 \mathrm{~min}$. The fiber used was a fiber of Polyacrylate ( $85 \mu \mathrm{m}$ film thickness), acquired from Supelco. Previous experiments [11] carried out in our laboratory on the study of the headspace components of other smoked foods using fibers of carboxen/polydimethylsiloxane, polydimethylsiloxane (100 $\mu \mathrm{m}$ film thickness) and polyacrylate $(85 \mu \mathrm{m}$ film thickness) have shown that: carboxen/polydimethylsiloxane fiber basically retained the most volatile components of the headspace, in very high proportions; however, polyacrylate fiber retained components of a broader volatility range; and polydimethylsiloxane fiber had less retention ability of smoke components than polyacrylate fiber.

\subsection{Gas chromatography/ mass spectrometry study}

Fibers with the adsorbed compounds were injected into a Hewlett-Packard gas chromatograph model HP 6890 Series II, equipped with a mass selective detector 5973 and a Hewlett-Packard Vectra XM Series 4 computer operating with the Chemstation program. The column used was a fused-silica capillary column $(60 \mathrm{~m}$ long $\times 0.25 \mathrm{~mm}$ inner diameter $\times 0.25 \mu \mathrm{m}$ film thickness; from Hewlett-Packard, Palo Alto, CA, USA), coated with a non-polar stationary phase (HP-5MS, 5\% phenyl methyl siloxane). The operation conditions were the following: the oven temperature was set initially at $45^{\circ} \mathrm{C}(0.50 \mathrm{~min}$ hold $)$, increased to $250{ }^{\circ} \mathrm{C}$ at $4{ }^{\circ} \mathrm{C} \cdot \mathrm{min}^{-1}(20 \mathrm{~min}$ hold); the temperatures of the ion source and the quadrupole mass analyzer were kept at 230 and $150{ }^{\circ} \mathrm{C}$, respectively; helium was used as carrier gas at a pressure of
$113.76 \mathrm{kPa}$; injector and detector temperatures were held at 220 and $280^{\circ} \mathrm{C}$, respectively; splitless mode was used for injection with a purge time of $5 \mathrm{~min}$. The fiber was maintained in the injection port for $10 \mathrm{~min}$. Mass spectra were recorded at an ionization energy of $70 \mathrm{eV}$. After the first desorption, the fiber was routinely desorbed for a second time in order to determine if the first process was complete.

The components were identified by their retention times, by their mass spectra, by comparing their mass spectra with those in a commercial library (Wiley 138L, Mass Spectral Database, Wiley 1990) and by using standards. All those compounds included in Table I were acquired commercially as pure compounds and used as standard for identification; in addition, 4-ethyloctanoic acid was also used to elucidate its presence or absence in the headspace of this cheese. Due to the overlapping of the signal of many compounds, semi-quantification was based on arbitrary units of the total current ion or of the base specific peak ion counts divided by $10^{5}$. Tables II and III give the average abundances $\left(\mathrm{A}_{\mathrm{a}}\right)$ obtained for some main components, as well as the average relative abundances $\left(\mathrm{A}_{\mathrm{ra}}\right)$ expressed as percentages, together with their deviations and the ion used for the quantification in each case.

\section{RESULTS AND DISCUSSION}

The number of detected compounds was very high, more than 330 . However, Table I gives only those compounds, identified by means of standards, found in the headspace of the exterior and/or interior regions of the cheese, as well as in a cross-section which represents the whole cheese sample. These have been grouped according to their nature in acids, alcohols, esters, aldehydes, ketones, hydrocarbons, furan and pyran derivatives, ethers, nitrogen derivatives, phenol, naphthalenol, diphenol, guaiacol and syringol derivatives, and others. The detected compounds showed a broad range of molecular weights and volatilities. 
Table I. Detected compounds in different cheese regions together with an indication of their concentration*.

\begin{tabular}{|c|c|c|c|c|c|}
\hline $\mathrm{N}^{\circ}$ & $\begin{array}{c}\mathrm{RT} \\
(\mathrm{min})\end{array}$ & $\begin{array}{c}\text { Compound } \\
\text { (molecular weight) }\end{array}$ & Exterior & Cross-section & Interior \\
\hline & & Acid & & & \\
\hline 1 & 5.85 & acetic acid $(60)$ & ++ & ++ & ++ \\
\hline 2 & 9.26 & butanoic acid (88) & ++ & ++ & ++ \\
\hline 3 & 12.65 & pentanoic acid (102) & $\operatorname{tr}$ & $\operatorname{tr}$ & $\operatorname{tr}$ \\
\hline 4 & 17.39 & hexanoic acid (116) & +++ & +++ & +++ \\
\hline 5 & 20.72 & heptanoic acid (130) & $\operatorname{tr}$ & $\operatorname{tr}$ & $\operatorname{tr}$ \\
\hline 6 & 22.48 & 2-ethyl-hexanoic acid (144) & $\operatorname{tr}$ & - & - \\
\hline 7 & 24.69 & benzoic acid (122) & $\operatorname{tr}$ & - & - \\
\hline 8 & 24.88 & octanoic acid (144) & +++ & +++ & +++ \\
\hline 9 & 27.99 & nonanoic acid (154) & + & + & $\operatorname{tr}$ \\
\hline \multirow[t]{2}{*}{10} & 30.69 & 4-hydroxy-3-methoxy-benzoic acid (168) & & & \\
\hline & & (vanillic acid) & $\operatorname{tr}$ & - & - \\
\hline 11 & 31.65 & decanoic acid (172) & +++ & +++ & +++ \\
\hline 12 & 37.54 & dodecanoic acid (200) & ++ & $\operatorname{tr}$ & $\operatorname{tr}$ \\
\hline 13 & 43.13 & tetradecanoic acid (228) & ++ & + & - \\
\hline 14 & 48.27 & hexadecanoic acid (256) & +++ & $\operatorname{tr}$ & - \\
\hline 15 & 52.34 & 9-octadecenoic acid (282) & ++ & - & - \\
\hline \multirow[t]{2}{*}{16} & 52.82 & octadecanoic acid (284) & + & $\operatorname{tr}$ & - \\
\hline & & Alcohols & & & \\
\hline 17 & 3.95 & ethanol (46) & ++ & ++ & ++ \\
\hline 18 & 9.78 & 2,3-butanediol (90) & ++ & ++ & ++ \\
\hline \multirow[t]{2}{*}{19} & 19.29 & benzenemethanol (108) & $\operatorname{tr}$ & $\operatorname{tr}$ & - \\
\hline & & Esters & & & \\
\hline 20 & 10.13 & ethyl butanoate (116) & - & $\operatorname{tr}$ & - \\
\hline 21 & 18.38 & ethyl hexanoate (144) & - & $\operatorname{tr}$ & $\operatorname{tr}$ \\
\hline 22 & 21.69 & methyl benzoate (136) & $\operatorname{tr}$ & $\operatorname{tr}$ & - \\
\hline 23 & 25.38 & ethyl octanoate (172) & - & - & $\operatorname{tr}$ \\
\hline 24 & 32.10 & ethyl decanoate (200) & - & $\operatorname{tr}$ & $\operatorname{tr}$ \\
\hline 25 & 36.40 & methyl dodecanoate (214) & $\operatorname{tr}$ & - & - \\
\hline \multirow{2}{*}{26} & 36.42 & methyl 4-hydroxy-3-methoxybenzoate (182) & & & \\
\hline & & (methyl vanillate) & $\operatorname{tr}$ & - & - \\
\hline 27 & 38.62 & ethyl dodecanoate (228) & - & $\operatorname{tr}$ & $\operatorname{tr}$ \\
\hline 28 & 42.11 & methyl tetradecanoate (242) & $\operatorname{tr}$ & - & - \\
\hline \multirow[t]{2}{*}{29} & 44.77 & ethyl tetradecanoate (256) & - & $\operatorname{tr}$ & $\operatorname{tr}$ \\
\hline & & Aldehydes & & & \\
\hline 30 & 16.14 & benzaldehyde (106) & $\operatorname{tr}$ & $\operatorname{tr}$ & $\operatorname{tr}$ \\
\hline 31 & 19.67 & benzeneacetaldehyde (120) & $\operatorname{tr}$ & $\operatorname{tr}$ & $\operatorname{tr}$ \\
\hline \multirow[t]{3}{*}{32} & 21.99 & nonanal (142) & $\operatorname{tr}$ & $\operatorname{tr}$ & $\operatorname{tr}$ \\
\hline & & Ketones & & & \\
\hline & & aliphatic linear and cyclic ketones and diketones & & & \\
\hline 33 & 7.28 & 3-hydroxy-2-butanone (88) & - & - & $\operatorname{tr}$ \\
\hline 34 & 9.25 & cyclopentanone (84) & $\operatorname{tr}$ & - & - \\
\hline 35 & 12.27 & 1-(acetyloxy)-2-propanone (116) & $\operatorname{tr}$ & - & - \\
\hline 36 & 13.10 & 2-heptanone (114) & $\operatorname{tr}$ & - & $\operatorname{tr}$ \\
\hline 37 & 13.31 & cyclohexanone (98) & $\operatorname{tr}$ & - & - \\
\hline
\end{tabular}


Table I. Continued.

\begin{tabular}{|c|c|c|c|c|c|}
\hline $\mathrm{N}^{\circ}$ & $\begin{array}{c}\mathrm{RT} \\
(\mathrm{min})\end{array}$ & $\begin{array}{c}\text { Compound } \\
\text { (molecular weight) }\end{array}$ & Exterior & Cross-section & Interior \\
\hline 38 & 13.88 & 2-methyl-2-cyclopenten-1-one (96) & $\operatorname{tr}$ & $\operatorname{tr}$ & - \\
\hline 39 & 15.00 & 2,5-hexanedione (114) & $\operatorname{tr}$ & - & - \\
\hline 40 & 16.43 & 3-methyl-2-cyclopenten-1-one (96) & $\operatorname{tr}$ & $\operatorname{tr}$ & - \\
\hline 41 & 17.95 & 3-methylcyclohexanone (112) & $\operatorname{tr}$ & $\operatorname{tr}$ & - \\
\hline 42 & 19.08 & 3-methyl-1,2-cyclopentanedione (112) (cyclotene) & + & + & $\operatorname{tr}$ \\
\hline 43 & 22.68 & $\begin{array}{l}\text { 3-ethyl-1,2-cyclopentanedione (126) } \\
\text { (3-ethylcyclopentenolone) }\end{array}$ & $\operatorname{tr}$ & $\operatorname{tr}$ & - \\
\hline 44 & 29.00 & 2-undecanone (170) & $\operatorname{tr}$ & - & - \\
\hline 45 & 35.57 & $\begin{array}{l}\text { 2-tridecanone }(198) \\
\text { aromatic ketones and related }\end{array}$ & $\operatorname{tr}$ & - & $\operatorname{tr}$ \\
\hline 46 & 20.58 & 1-phenyl-ethanone (120) (acetophenone) & $\operatorname{tr}$ & $\operatorname{tr}$ & - \\
\hline 47 & 34.95 & 2,5-di-tert-butyl-1,4-benzoquinone (220) & $\operatorname{tr}$ & - & - \\
\hline 48 & 35.50 & $\begin{array}{l}\text { 1-(4-hydroxy-3-methoxyphenyl)-ethanone (166) } \\
\text { (acetovanillone) }\end{array}$ & $\operatorname{tr}$ & $\operatorname{tr}$ & $\operatorname{tr}$ \\
\hline 49 & 35.50 & $\begin{array}{l}\text { 1-(4-hydroxy-3-methoxyphenyl)-2-propanone (180) } \\
\text { (propiovanillone) }\end{array}$ & $\operatorname{tr}$ & - & - \\
\hline 50 & 36.86 & $\begin{array}{l}\text { 1-(4-hydroxy-3,5-dimethoxyphenyl)-ethanone (196) } \\
\text { (acetosiringone) } \\
\text { Hydrocarbons } \\
\text { aliphatic hydrocarbons }\end{array}$ & $\operatorname{tr}$ & - & - \\
\hline 51 & 38.60 & hexadecane (226) & $\operatorname{tr}$ & - & - \\
\hline 52 & 41.26 & heptadecane (240) & + & + & - \\
\hline 53 & 44.10 & octadecane (254) & $\operatorname{tr}$ & - & - \\
\hline 54 & 49.28 & eicosene (282) & $\operatorname{tr}$ & - & - \\
\hline 55 & 65.87 & $\begin{array}{l}\text { squalene }(410) \\
\text { polyaromatic hydrocarbons }\end{array}$ & $\operatorname{tr}$ & $\operatorname{tr}$ & - \\
\hline 56 & 25.29 & naphthalene (128) & $\operatorname{tr}$ & $\operatorname{tr}$ & - \\
\hline 57 & 29.32 & 2-methylnaphthalene (142) & $\operatorname{tr}$ & $\operatorname{tr}$ & - \\
\hline 58 & 29.91 & 1-methylnaphthalene (142) & $\operatorname{tr}$ & - & - \\
\hline 59 & 34.52 & acenaphthylene (152) & $\operatorname{tr}$ & - & - \\
\hline 60 & 44.18 & $\begin{array}{l}\text { phenanthrene (178) } \\
\text { Furan, pyran derivatives and others }\end{array}$ & $\operatorname{tr}$ & - & - \\
\hline 61 & 10.80 & 2-furancarboxaldehyde (96) & $\operatorname{tr}$ & - & - \\
\hline 62 & 11.84 & 2-furanmethanol (98) (furfuryl alcohol) & $\operatorname{tr}$ & $\operatorname{tr}$ & $\operatorname{tr}$ \\
\hline 63 & 14.02 & 1-(2-furanyl)-ethanona (110) (2-acetylfuran) & $\operatorname{tr}$ & $\operatorname{tr}$ & $\operatorname{tr}$ \\
\hline 64 & 14.48 & $2(5 \mathrm{H})$-furanone $(84)(\gamma$-crotonolactone $)$ & $\operatorname{tr}$ & $\operatorname{tr}$ & $\operatorname{tr}$ \\
\hline 65 & 15.51 & 5-methyl-2(5H)-furanone (98) & $\operatorname{tr}$ & - & - \\
\hline 66 & 16.27 & 5-methyl-2-furancarboxaldehyde (110) & $\operatorname{tr}$ & - & - \\
\hline 67 & 19.75 & 3-methyl-2(5H)-furanone (98) & $\operatorname{tr}$ & $\operatorname{tr}$ & - \\
\hline 68 & 22.43 & 3-hydroxy-2-methyl-4H-pyran-4-one (126) (maltol) & + & $\operatorname{tr}$ & $\operatorname{tr}$ \\
\hline 69 & 28.86 & $\delta$-octalactone $(142)$ & $\operatorname{tr}$ & $\operatorname{tr}$ & $\operatorname{tr}$ \\
\hline 70 & 34.88 & $\gamma$-decalactone (170) & - & $\operatorname{tr}$ & - \\
\hline 71 & 35.29 & $\begin{array}{l}\text { 1,6-anhydro- } \beta \text {-D-glucopyranose (162) } \\
\text { (levoglucosan) }\end{array}$ & $\operatorname{tr}$ & - & - \\
\hline 72 & 35.78 & $\delta$-decalactone $(170)$ & $\operatorname{tr}$ & $\operatorname{tr}$ & $\operatorname{tr}$ \\
\hline 73 & 41.09 & $\gamma$-dodecalactone (198) & $\operatorname{tr}$ & $\operatorname{tr}$ & $\operatorname{tr}$ \\
\hline 74 & 41.91 & 4-dodecalactone (198) & $\operatorname{tr}$ & $\operatorname{tr}$ & - \\
\hline
\end{tabular}


Table I. Continued.

\begin{tabular}{|c|c|c|c|c|c|}
\hline $\mathrm{N}^{\circ}$ & $\begin{array}{c}\mathrm{RT} \\
(\min )\end{array}$ & $\begin{array}{c}\text { Compound } \\
\text { (molecular weight) }\end{array}$ & Exterior & Cross-section & Interior \\
\hline & & Ethers & & & \\
\hline 75 & 23.64 & 1,2-dimethoxybenzene (138) & $\operatorname{tr}$ & $\operatorname{tr}$ & - \\
\hline 76 & 24.96 & 1,4-dimethoxybenzene (138) & $\operatorname{tr}$ & $\operatorname{tr}$ & - \\
\hline \multirow[t]{2}{*}{77} & 25.22 & 1,3-dimethoxybenzene (138) & $\operatorname{tr}$ & $\operatorname{tr}$ & - \\
\hline & & $\begin{array}{l}\text { Phenolic derivatives } \\
\text { phenol derivatives }\end{array}$ & & & \\
\hline 78 & 16.95 & phenol (94) & ++ & + & $\operatorname{tr}$ \\
\hline 79 & 19.98 & 2-methylphenol (108) & ++ & + & - \\
\hline 80 & 20.81 & 4-methylphenol (108) and 3-methylphenol (108) & ++ & + & - \\
\hline 81 & 22.15 & 2,6-dimethylphenol (122) & + & $\operatorname{tr}$ & - \\
\hline 82 & 23.28 & 2-ethylphenol (122) & + & $\operatorname{tr}$ & - \\
\hline 83 & 23.68 & 2,4-dimethylphenol (122) & + & $\operatorname{tr}$ & - \\
\hline 84 & 23.73 & 2,5-dimethylphenol (122) & + & $\operatorname{tr}$ & - \\
\hline 85 & 24.27 & 4-ethylphenol (122) & + & $\operatorname{tr}$ & - \\
\hline 86 & 24.46 & 3-ethylphenol (122) & + & $\operatorname{tr}$ & - \\
\hline 87 & 30.65 & 2-(1,1-dimethylethyl)-4-methyl-phenol (164) & $\operatorname{tr}$ & - & - \\
\hline 88 & 36.11 & 2,4-bis(1,1-dimethylethyl)-phenol (206) & $\operatorname{tr}$ & - & - \\
\hline \multirow[t]{3}{*}{89} & 36.29 & 2,6-bis(1,1-dimethylethyl)-4-methyl-phenol (220) & & & \\
\hline & & (BHT) & $\operatorname{tr}$ & $\operatorname{tr}$ & - \\
\hline & & diphenol derivatives & & & \\
\hline \multirow[t]{2}{*}{90} & 23.57 & 3-methoxy-1,2-benzenediol (140) & & & \\
\hline & & (3-methoxypyrocatechol) & $\operatorname{tr}$ & $\operatorname{tr}$ & - \\
\hline 91 & 25.68 & 1,2-benzenediol (110) (pyrocatechol) & $\operatorname{tr}$ & - & - \\
\hline \multirow[t]{3}{*}{92} & 27.90 & 3-methyl-1,2-benzenediol (124) & & & \\
\hline & & (3-methylpyrocatechol) & $\operatorname{tr}$ & - & - \\
\hline & & methoxyphenol derivatives & & & \\
\hline 93 & 21.49 & 2-methoxyphenol (guaiacol) (124) & +++ & ++ & $\operatorname{tr}$ \\
\hline \multirow[t]{2}{*}{94} & 25.50 & 4-methyl-2-methoxyphenol (138) & & & \\
\hline & & (4-methylguaiacol) & ++ & + & $\operatorname{tr}$ \\
\hline 95 & 28.62 & 4-ethyl-2-methoxyphenol (152) (4-ethylguaiacol) & ++ & $\operatorname{tr}$ & - \\
\hline 96 & 29.82 & 4-vinyl-2-methoxyphenol (150) (4-vinylguaiacol) & ++ & $\operatorname{tr}$ & - \\
\hline 97 & 31.31 & 4-(2-propenyl)-2-methoxyphenol (164) (eugenol) & + & $\operatorname{tr}$ & - \\
\hline \multirow[t]{2}{*}{98} & 32.06 & 4-propyl-2-methoxyphenol (166) & & & \\
\hline & & (4-propylguaiacol) & + & $\operatorname{tr}$ & - \\
\hline 99 & 32.74 & $\begin{array}{l}\text { 4-hydroxy-3-methoxy-benzaldehyde (152) } \\
\text { (vanillin) }\end{array}$ & $\operatorname{tr}$ & $\operatorname{tr}$ & - \\
\hline 100 & 32.98 & 4-(1-propenyl)-2-methoxyphenol (164) (isoeugenol) & + & $\operatorname{tr}$ & - \\
\hline \multirow[t]{2}{*}{101} & 34.30 & 4-(1-propenyl)-2-methoxyphenol (164) (isoeugenol) & + & $\operatorname{tr}$ & - \\
\hline & & dimethoxyphenol derivatives & & & \\
\hline 102 & 31.03 & 2,6-dimethoxyphenol (154) (syringol) & ++ & + & - \\
\hline \multirow[t]{2}{*}{103} & 34.17 & 4-methyl-2,6-dimethoxyphenol (168) & & & \\
\hline & & (4-methylsyringol) & + & $\operatorname{tr}$ & - \\
\hline 104 & 38.91 & 4-(2-propenyl)-2,6-dimethoxyphenol (194) & $\operatorname{tr}$ & $\operatorname{tr}$ & - \\
\hline
\end{tabular}

* Great number of area counts: +++; medium number of area counts: ++; small number of area counts: +; very low number of area counts: tr; no detected: -. Data in Tables II and III give an approximate idea of the signification of these symbols. 
Acids formed the most important group by concentration, making up nineteen components, present in both the exterior and in the interior region. Most were saturated linear acids, ranging between two and eighteen carbon atoms, with an even or uneven number of carbon atoms, the first in higher concentrations than the second; the origin of these acids can be found in the triglyceride hydrolysis, although other routes are also possible. The importance of hexanoic, octanoic and decanoic acids in goat's cheese flavor has been well known for a long time [3]. Only one branched-chain, 2-ethyl-hexanoic acid, and one unsaturated, 9-octadecenoic acid, were detected. Although 4-methyl- and 4-ethyl-octanoic acids have been considered by different authors as characteristic of goat's cheese [16, 31], these acids were not detected in any of these artisanal Palmero cheese samples studied.

The number of identified alcohols was low. Linear alcohols were present both in the exterior and in the interior region and may be formed by different processes from lactose, aminoacids, or acids [26].

The ester group contained mainly methyl or ethyl ester derivatives. Most of these components come from reactions between acids and alcohols and some of them were detected not only in the exterior but also in the interior region. One should note the presence, in the exterior region, of benzoate as well as of vanillate esters, these latter probably derived from the corresponding acid also detected; although compounds of this nature have not been very often detected in cheese, they contribute not only organoleptic [21] but also preserving properties [29]; it should be noted that methyl vanillate has been included in formulations to reproduce blue cheese flavors [24].

A reduced number of aliphatic and aromatic aldehydes were also identified at very low concentrations. Ketones were very numerous. Some of these, such as 1-(acetyloxy)-2-propanone, the cyclic mono- and di-ketones, and the aromatic ketones are well-known smoke components [12]. Most of them were only present in the exterior region, except acetovanillone and cyclotene. The diffusion of these latter towards the interior region could be due to different factors such as: their concentration in the exterior region; the size and shape of the compound; or the ability of the compound to establish interactions with the components of the cheese matrix.

In the group of hydrocarbons, aliphatics and aromatics were detected. The main aliphatic hydrocarbon was heptadecane. The origin of the polyaromatic hydrocarbons could be found in the smoke, although those of low molecular weight have also been detected in unsmoked cheese $[4,10$, 22]. Most of the detected hydrocarbons were only found in the exterior region.

The furan and pyran derivatives consisted of two different types of components: those from the smoke, covering from 2-furancarboxaldehyde to maltol and related derivatives, and the group of $\gamma$ - and $\delta$-lactones from the cyclation of hydroxyacids. All these compounds were only detected as trace amounts. Of the components from the smoke, only some, such as 2-furanmethanol, 2-acetylfuran, $\gamma$-crotonolactone and maltol, had diffused towards the interior cheese region. Levoglucosan or 1,6-anhydro- $\beta$-D-glucopyranose is an anhydrosugar derived from cellulose thermal degradation and is a main smoke component [14]. Lactones were detected mainly in the exterior and only $\delta$-octalactone, $\delta$-decalactone and $\gamma$-dodecalactone were detected in the interior region.

The ethers identified were alkyl-aryl ethers and probably come from the smoke, being mainly present in the cheese's exterior region. It is worth noting that a significant group of nitrogenated compounds, basically nitrile, quinoline and indol derivatives, was detected but not included in Table I because their identification was not based on standard compounds.

The most numerous group of components was that of phenolic derivatives, constituted by phenol, diphenol, methoxyphenol (guaiacol) 
and dimethoxyphenol (syringol) derivatives. Although some phenol derivatives have been detected in certain unsmoked cheeses, most of these phenolic derivatives come from the smoke. The presence of diphenol derivatives, compounds with well-known antioxidant ability, was significant, as was that of syringol and some of its alkyl derivatives. In spite of the high number of phenolic derivatives detected in the exterior region, only phenol, guaiacol and 4-methyl-guaiacol reached the interior region.

Although the smoke contained higher proportions of compounds from the thermal degradation of wood carbohydrates (aldehydes, ketones, anhydrosugars, acids and furan and pyran derivatives) than from wood lignin (phenolic derivatives) [13], in the headspace of all studied cheeses there were higher proportions of phenolic derivatives than of compounds from carbohydrate pyrolysis. This fact could be: due to these latter being retained more strongly in cheese matrix than the phenolic derivatives; or due to compounds derived from carbohydrate having less affinity to being retained on the fiber than phenolic derivatives; or because they react with cheese components by reactions similar to the Maillard reaction, modifying the texture and the color of the cheese and disappearing from the system.

The headspace of the cheese's exterior region is much richer in components than the headspace of the interior region. This is because the majority of the smoke components present in the exterior region do not diffuse towards the interior of the cheese and because some important reactions which generate volatile compounds, such as esterification and oxidation processes, are probably favored in the exterior region. Smoke components identified in the interior region were cyclotene, acetovanillone, 2 -furanmethanol, acetylfuran, $\gamma$-crotonolactone, maltol, phenol, guaiacol and 4-methylguaiacol. Although the contribution of each smoke component was not determined since the corresponding threshold values are unknown, smoke components are likely to influence cheese flavor and this should be taken into account, in particular in the preparation of samples for sensory evaluations.

Figures 1 and 2 show the total current ion chromatograms of the headspace components of the exterior, interior and crosssection of the samples T3 and T4; these cheese samples had the highest concentration in smoke components and in acids, respectively, of all those studied here. It can be observed that in both samples the smoke components' concentration diminished from the exterior towards the interior, whereas the acids' concentration was fairly constant in both cheese regions inside the same sample. So, while in the interior region of both samples (Figs. 1c, 2c), hexanoic, octanoic and decanoic acids predominated, in the exterior region of sample T3 (Fig. 1a) phenolic derivatives predominated, and in the exterior region of sample T4 (Fig. 2a), acids together with phenolic derivatives predominated, showing a great difference in composition between the two regions inside the same cheese sample.

As has been commented on before, these six cheese samples were made by artisans; for this reason, there was a certain variability among the samples. So, T3 was the cheese sample whose headspace had the highest concentrations in smoke components, and the others, T1, T2, T4, T5 and T6, showed lower concentrations of these kinds of components. This variability can be observed in Table II, which gives the cheese's headspace average abundances $\left(\mathrm{A}_{\mathrm{a}}\right)$ together with the standard deviations $\left(\mathrm{DA}_{\mathrm{a}}\right)$ of some smoke components in samples T1, T2, T4, T5 and T6. In spite of the different smoking degree undergone by these cheeses, the average relative abundances $\left(\mathrm{A}_{\mathrm{ra}}\right)$ of the smoke components of the six samples, expressed as percentages in relation to the total abundance, given in Table II, reveal that these cheese show a fairly homogeneous aromatic profile of smoke components, mainly made up of 


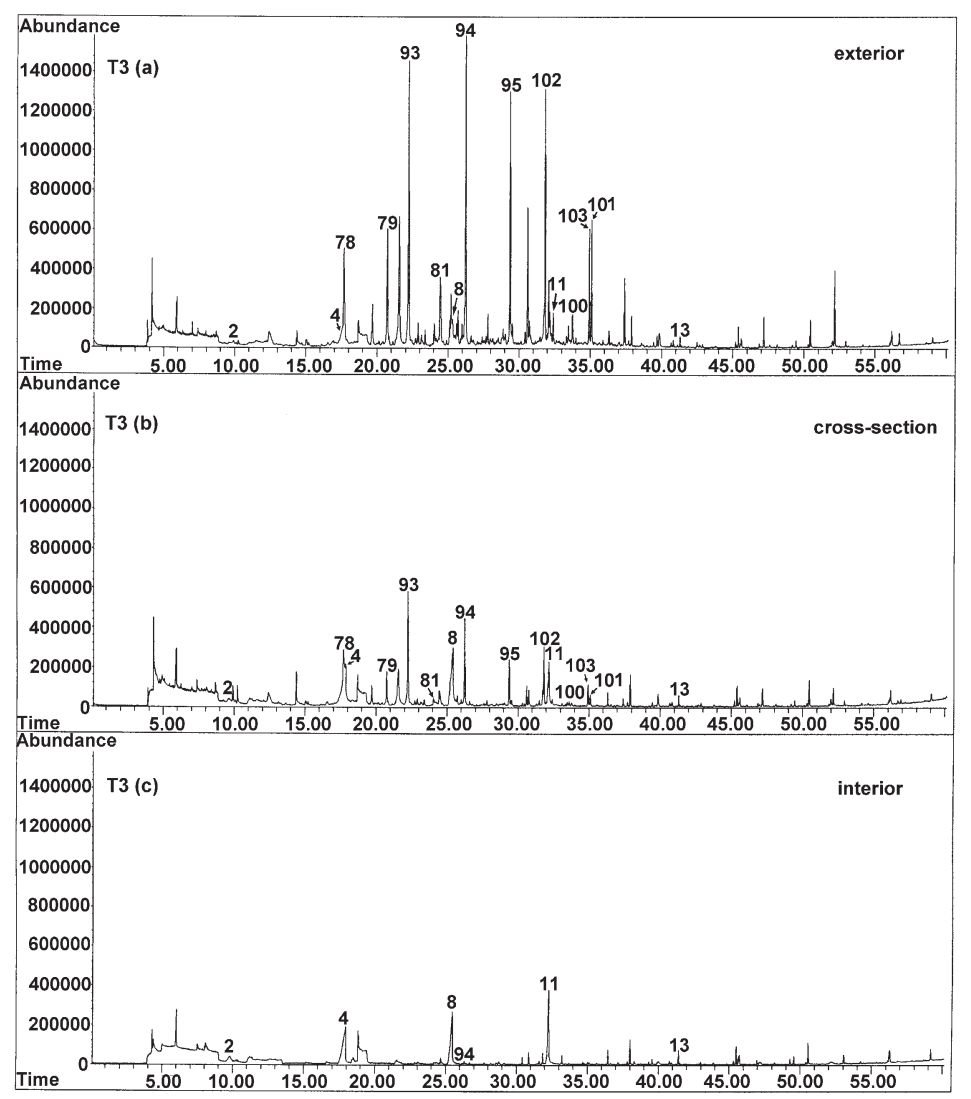

Figure 1. Total ion current chromatogram of the components of the headspace of the exterior (a), cross-section (b) and interior regions (c) of the T3 cheese sample, which contains the highest concentrations in smoke components. The numbers of the components agree with those in Table I.

phenol, guaiacol, 4-methyl- and 4-ethylguaiacol, syringol, methyl-phenols and vinyl-guaiacol in quite constant proportions.

Likewise, differences were found between samples in relation to acid concentrations. So, in T1 and T4 headspace samples the concentration of acids is much higher than in the other samples due to an accentuation of the lipolysis process. Table III gives the cheese's headspace average abundances $\left(A_{a}\right)$ of the main acids in samples T2, T3, $\mathrm{T} 5$ and T6. These data indicate that there is a great variability in the abundance of acids in the different cheeses, probably due to the accentuation of the lipolysis process in the manufacture of some samples. In spite of this, the average relative abundance $\left(\mathrm{A}_{\mathrm{ra}}\right)$ of significant acids of the six samples, expressed as percentages in relation to the total abundance, given in Table III, reveal that these cheeses showed a fairly homogeneous aromatic profile of acids, the main ones being hexanoic, octanoic and decanoic, in quite constant proportions.

The headspace of Palmero cheeses smoked with dry prickly pear shows some differences in relation to the headspace of Palmero cheeses smoked with pine needles [15]. 


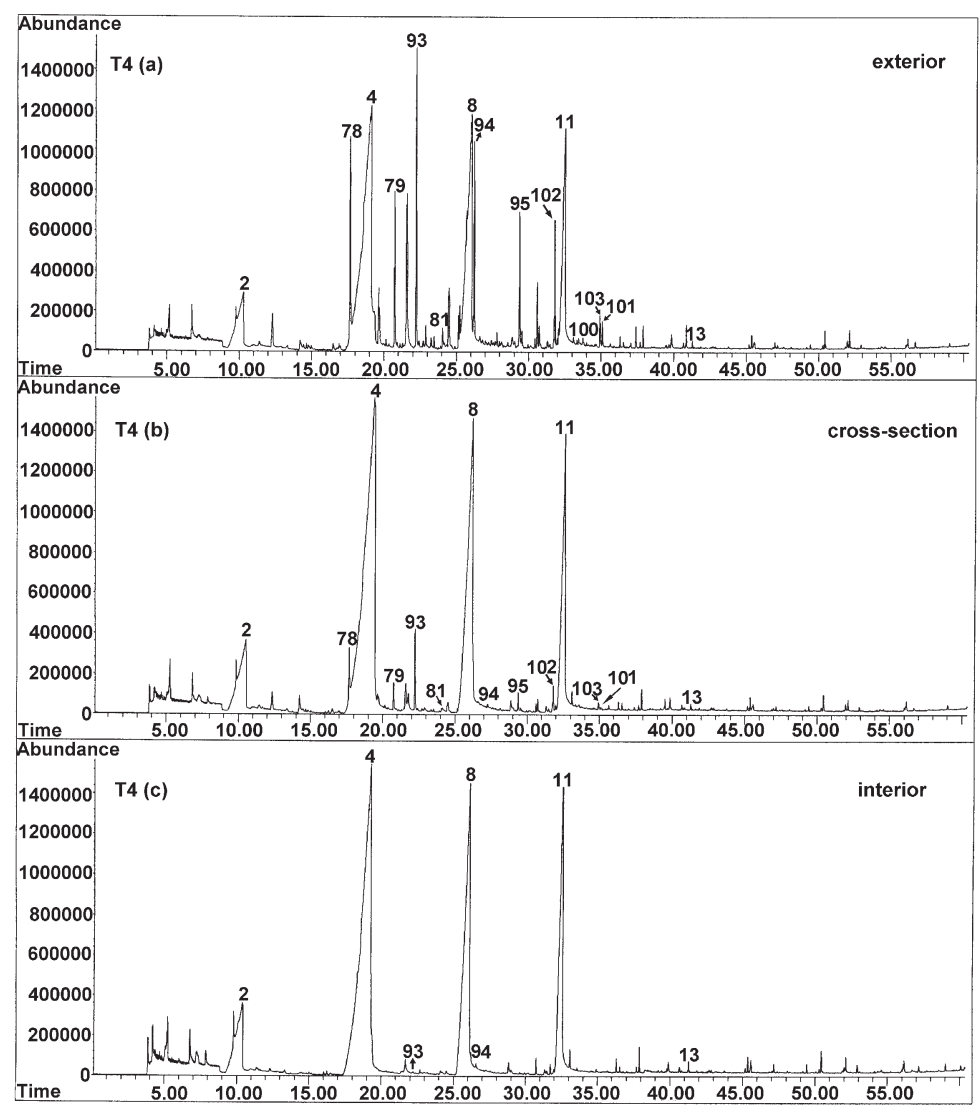

Figure 2. Total ion current chromatogram of the components of the headspace of the exterior (a), cross-section (b) and interior regions (c) of the T4 cheese sample, which contains the highest concentrations in acids. The numbers of the components agree with those in Table I.

In general, the average concentrations of smoke components in the headspace of all samples of cheese smoked with dry prickly pear, and their standard deviations, were lower than in those of cheese smoked with pine needles; this fact indicates that both the smoking degree reached and the variability among samples is lower in the case of dry prickly pear. As the manufacture and smoking process of this cheese is artisanal, both facts mentioned are related to the influence of the vegetable matter on the performance of the pyrolytic process for obtaining smoke with homogeneous composition and concentration. As previously commented, there are also differences in relation to the presence or absence of components derived from the smoke. So, the absence of terpene and sesquiterpene compounds in the headspace of cheese smoked with dry prickly pear is noteworthy, as is the presence of biphenol derivatives, as well as a more accentuated presence of nitrogen and syringol derivatives than in the headspace of cheese smoked with pine leaves. Differences in the headspace of Palmero cheese smoked with 
Table II. Average abundances, $\mathrm{A}_{\mathrm{a}}$, and average relative abundances, $\mathrm{A}_{\mathrm{ra}}$ of some components derived from the smoke, in the headspace of the exterior cheese region, calculated from data of five (T1, T2, T4, T5, T6) and of six samples, respectively, expressed in area counts of the ion used for the quantification (I) multiplied by $10^{-5}$, and as percentages, respectively, together with their standard deviations, $\mathrm{DA}_{\mathrm{a}}$ and $\mathrm{DA}_{\mathrm{ra}}$.

\begin{tabular}{|c|c|c|c|c|c|}
\hline Compounds & I & $\mathrm{A}_{\mathrm{a}}$ & $\mathrm{DA}_{\mathrm{a}}$ & $\mathrm{A}_{\mathrm{ra}}$ & $\mathrm{DA}_{\mathrm{ra}}$ \\
\hline 2-Furanmethanol (furfuryl alcohol) & 98 & 14.6 & \pm 4.9 & 1.8 & \pm 1.0 \\
\hline 3-Methyl-1,2-cyclopentanedione (cyclotene) & 112 & 6.1 & \pm 1.5 & 0.9 & \pm 0.4 \\
\hline 3-Hydroxy-2-methyl-4H-pyran-4-one (maltol) & 126 & 4.0 & \pm 1.3 & 0.6 & \pm 0.2 \\
\hline Phenol & 94 & 154.0 & \pm 61.1 & 16.9 & \pm 4.1 \\
\hline 2-Methylphenol & 108 & 48.3 & \pm 14.3 & 5.8 & \pm 0.5 \\
\hline 4-Methylphenol and 3-Methylphenol & 107 & 100.8 & \pm 29.6 & 11.7 & \pm 2.1 \\
\hline 2,6-Dimethylphenol & 122 & 5.7 & \pm 1.7 & 0.7 & \pm 0.1 \\
\hline 2-Ethylphenol & 107 & 5.5 & \pm 1.3 & 0.7 & \pm 0.1 \\
\hline 2,4-Dimethylphenol and 2,5-Dimethylphenol & 107 & 32.0 & \pm 7.9 & 4.0 & \pm 0.4 \\
\hline 2,3-Dimethylphenol & 107 & 5.7 & \pm 1.3 & 0.7 & \pm 0.1 \\
\hline 2,6-Bis(1,1-dimethylethyl)-4-methyl-phenol (BHT) & 205 & 2.7 & \pm 1.3 & 0.3 & \pm 0.2 \\
\hline 2-Methoxyphenol (guaiacol) & 109 & 113.4 & \pm 28.2 & 13.9 & \pm 1.5 \\
\hline 4-Methyl-2-methoxyphenol (4-methylguaiacol) & 138 & 78.9 & \pm 24.9 & 9.9 & \pm 1.6 \\
\hline 4-Ethyl-2-methoxyphenol (4-ethylguaiacol) & 137 & 96.3 & \pm 28.5 & 12.2 & \pm 1.4 \\
\hline 4-Vinyl-2-methoxyphenol (4-vinylguaiacol) & 150 & 47.3 & \pm 21.2 & 5.6 & \pm 1.4 \\
\hline 4-(2-Propenyl)-2-methoxyphenol (eugenol) & 164 & 8.3 & \pm 3.2 & 1.1 & \pm 0.3 \\
\hline 4-Propyl-2-methoxyphenol (4-propylguaiacol) & 137 & 13.1 & \pm 4.7 & 1.7 & \pm 0.4 \\
\hline 4-(1-Propenyl)-2-methoxyphenol (isoeugenol) & 164 & 4.3 & \pm 1.7 & 0.6 & \pm 0.2 \\
\hline 4-(1-Propenyl)-2-methoxyphenol (isoeugenol isomer) & 164 & 16.1 & \pm 6.2 & 2.2 & \pm 0.8 \\
\hline 2,6-Dimethoxyphenol (syringol) & 154 & 38.5 & \pm 9.0 & 5.8 & \pm 2.7 \\
\hline 4-Methyl-2,6-dimethoxyphenol (4-methylsyringol) & 168 & 13.9 & \pm 2.1 & 2.2 & \pm 1.0 \\
\hline 4-(2-Propenyl)-2,6-dimethoxyphenol & 194 & 1.0 & \pm 0.3 & 0.2 & \pm 0.1 \\
\hline Naphthalene & 128 & 3.9 & \pm 1.3 & 0.4 & \pm 0.1 \\
\hline 2-Methylnaphthalene & 142 & 0.8 & \pm 0.3 & 0.1 & \pm 0.0 \\
\hline Acenaphthylene & 152 & 0.6 & \pm 0.4 & 0.1 & \pm 0.0 \\
\hline
\end{tabular}

dry prickly pear and pine needles can also be found in the proportions of some phenolic derivatives such as 2-methylphenol in relation to phenol, 4-methylguaiacol and 4-ethylguaiacol in relation to guaiacol, and 4-methylsyringol in relation to syringol, due to the differences in the lignin composition of the vegetable matters used for the smoking. In relation to typical headspace cheese components such as acids, it can be said that their number, their average concentrations and their standard deviations, which represent the variability among samples, are also smaller in cheeses smoked with dry prickly pear than in those smoked with pine leaves.

In conclusion, in the headspace of this cheese typical cheese components and typical smoke components were identified. 
Table III. Average abundances, $\mathrm{A}_{\mathrm{a}}$, and average relative abundances, $\mathrm{A}_{\mathrm{ra}}$ of the acids in the headspace of the exterior cheese region, calculated from data of four (T2, T3, T5, T6) and of six samples, respectively, expressed in area counts of the ion used for the quantification (I) multiplied by $10^{-5}$ and as percentages, respectively, together with their standard deviations, $\mathrm{DA}_{\mathrm{a}}$ and $\mathrm{DA}_{\mathrm{ra}}$.

\begin{tabular}{lccccc}
\hline Compounds & $\mathrm{I}$ & $\mathrm{A}_{\mathrm{a}}$ & $\mathrm{DA}_{\mathrm{a}}$ & $\mathrm{A}_{\mathrm{ra}}$ & $\mathrm{DA}_{\mathrm{ra}}$ \\
\hline Pentanoic acid & 60 & 6.1 & \pm 4.7 & 1.4 & \pm 1.5 \\
Hexanoic acid & 60 & 91.5 & \pm 27.6 & 37.3 & \pm 9.8 \\
Octanoic acid & 60 & 94.6 & \pm 22.2 & 30.4 & \pm 4.1 \\
Nonanoic acid & 60 & 2.3 & \pm 0.9 & 0.6 & \pm 0.3 \\
Decanoic acid & 60 & 89.7 & \pm 19.3 & 27.7 & \pm 5.9 \\
Dodecanoic acid & 73 & 7.6 & \pm 2.2 & 2.5 & \pm 1.4 \\
\hline
\end{tabular}

Among the first group of components only some of them are homogeneously distributed in the different cheese regions, the exterior region being generally richer in components than the interior. Most of the components of the second group are present only in the exterior region; however, some of them have diffused towards the interior region. It must be pointed out that although phenolic derivatives are not the main smoke components, nevertheless, in the headspace exterior region these compounds were the smoke components detected in the highest proportions. In spite of the differences found in the headspace component concentrations of the exterior region of the several samples, there is a certain homogeneity shown by similar proportions not only of the smoke components but also of the main acids. The most significant differences in the headspace composition of Palmero cheese smoked with prickly pear and with pine leaves are that the first contains a higher number of syringol and nitrogenated derivatives than the second, and this latter contains terpene derivatives absent in the first. These differences in composition between Palmero cheese smoked with pine leaves and with dry prickly pear allows one to distinguish between the two kinds of cheeses.

Acknowledgements: This work has been supported by the Comisión Interministerial de Ciencia y Tecnología and Ministerio de Ciencia y Tecnología (MCYT, AGL2003-01838 and CAL00-054-C3-2), and the Universidad del
País Vasco (9/UPV 00101.125.13667/2001). G. Palencia thanks the Universidad del País Vasco for a predoctoral fellowship. We thank the Palmero Artisans and the Consejo Regulador de la Denominacion de Origen Protegida de Queso Palmero for the cheese samples.

\section{REFERENCES}

[1] Bosset J.O., Butikofer U., Gauch R., Sieber R., Occurrence of terpenes and aliphatic hydrocarbons in Swiss Gruyere and Etivaz alpine cheese using dynamic headspace GCMS analysis of their volatile flavour compounds, Schweiz. Milchwirt. Forsch. 23 (1994) 37-42.

[2] Bosset J.O., Butikofer U., Dafflon O., Koch H., Scheurer-Simonet L., Sieber R., Occurrence of polycyclic aromatic hydrocarbons in cheese with and without a smoked flavor, Sci. Aliments 18 (1998) 347-359.

[3] Brandsaeter E., Abate V., Flavor compounds in goat milk and goat-whey cheese, Meldinger Norg. Landbruks. 38 (1959) 11 p.

[4] Careri M., Manini P., Spagnoli S., Barbieri G., Bolzoni L., Simultaneous distillationextraction and dynamic headspace methods in the gas chromatographic analysis of Parmesan cheese volatiles, Chromatographia 38 (1994) 386-394.

[5] De Frutos M., Sanz J., Martinez-Castro I., Characterization of artisanal cheeses by GC and GC/MS analysis of their medium volatility (SDE) fraction, J. Agric. Food Chem. 39 (1991) 524-530.

[6] Engel E., Nicklaus S., Septier C., Salles C., Le Quéré J.L., Determination of the taste active compounds of a goat cheese watersoluble extract, in: 9th proceedings of the Weurman flavour research symposium, June 
22-25, Deutsche Forschungsanstalt für Lebensmittelchemie, Garching, Germany, 1999, pp. 84-88.

[7] Engel E., Nicklaus S., Garem A., Septier C., Salles C., Le Quéré J.L., Taste active compounds in a goat cheese water-soluble extract. 1. Development and sensory validation of a model water-soluble extract, J. Agric. Food Chem. 48 (2000) 4252-4259.

[8] Fresno M., Fernández M., Alvarez S., Darmanin N., Batista P., Pino V., Caracterización del proceso de ahumado del queso Palmero, Alimentación, Equipos y Tecnología 173 (2002) 87-92.

[9] Gaborit P., Menard A., Morgan F., Impact of ripening strains on the typical flavour of goat cheeses, Int. Dairy J. 11 (2001) 315-325.

[10] Guichard E., Berdagué J.L., Grappin R., Ripening and quality of Gruyère of Comté cheese. Change in the amounts of volatile compounds in relation to season of manufacture and ripening conditions, Lait 67 (1987) 319-337.

[11] Guillén M.D., Errecalde M.C., Volatile components of raw and smoked black bream (Brama raii) and rainbow trout (Oncorhynchus mykiss) studied by means of solid phase microextraction and gas chromatography/ mass spectrometry, J. Sci. Food Agric. 82 (2002) 945-952.

[12] Guillén M.D., Ibargoitia M.L., Relationships between the maximum temperature reached in the smoke generation processes from Vitis vinifera $\mathrm{L}$. shoot sawdust and composition of the aqueous smoke flavoring preparations obtained, J. Agric. Food Chem. 44 (1996) 1302-1307.

[13] Guillén M.D., Manzanos M.J., Study of the volatile composition of an aqueous oak smoke preparation, Food Chem. 79 (2002) 283-292.

[14] Guillén M.D., Manzanos M.J., Ibargoitia M.L., Carbohydrate and nitrogenated compounds in liquid smoke flavorings, J. Agric. Food Chem. 49 (2001) 463-468.

[15] Guillén M.D., Ibargoitia M.L., Sopelana P., Palencia G., Fresno M., Components detected by means of solid phase microextraction and gas chromatography/mass spectrometry in the headspace of artisan fresh goat cheese smoked by traditional methods, J. Dairy Sci. 87 (2004) 284-299.

[16] Ha J.K., Lindsay R.C., Volatile branchedchain fatty acids and phenolic compounds in aged Italian cheese flavours, J. Food Sci. 56 (1991) 1241-1247, 1250.

[17] Izco J.M., Torre P., Characterisation of volatile flavour compounds in Roncal cheese extracted by the "purge and trap" method and analysed by GC-MS, Food Chem. 70 (2000) 409-417.

[18] Jaillais B., Bertrand V., Auger J., Cryo-trapping/ SPME/ GC analysis of cheese aroma, Talanta 48 (1999) 747-753.

[19] Kubícková J., Grosch W., Evaluation of potent odorants of Camembert cheese by dilution and concentration techniques, Int. Dairy J. 7 (1997) 65-70.

[20] Larráyoz P., Ibañez F.C., Ordoñez A.I., Torre P., Barcina Y., Evaluation of supercritical fluid extraction as sample preparation method for the study of Roncal cheese aroma, Int. Dairy J. 10 (2001) 755-759.

[21] Luebke M., Le Quéré J.L., Barron D., Prefractionation of aroma extracts from fat-containing food by high-performance sizeexclusion chromatography, J. Chromatogr. A 729 (1996) 371-379.

[22] Martinez-Castro I., Sanz J., Amigo L., Ramos M., Martin-Alvarez P., Volatile components of Manchego cheese, J. Dairy Res. 58 (1991) 239-246.

[23] Mehaia M.A., Manufacture of fresh soft white cheese (Domiati-type) from ultrafiltered goats' milk, Food Chem. 79 (2002) 445452.

[24] Moinas M., Groux M.J.A., Hormann I., Aroma compositions for imparting a camembert or blue cheese flavor to foods, Patentschrift (Switz.), CH552949, 1974.

[25] Moio L., Piombino P., Addeo F., Odourimpact compounds of Gorgonzola cheese, J. Dairy Res. 67 (2000) 273-285.

[26] Molimard P., Spinnler H.E., Review: Compounds involved in the flavor of surface mold-ripened cheeses: origins and properties, J. Dairy Sci. 79 (1996) 169-184.

[27] Molina E., Ramos M., Alonso L., LopezFandino R., Contribution of low molecular weight water soluble compounds to the taste of cheeses made of cows', ewes' and goats' milk, Int. Dairy J. 9 (1999) 613-621.

[28] Parliment T.H., Kolor M.G., Rizzo D.J., Volatile components of Limburger cheese, J. Agric. Food Chem. 30 (1982) 1006-1008.

[29] Pearl I.A., McCoy J.F., Vanillic acid esters as food preservatives, Food Ind. 17 (1945) 1458-1461, 1600, 1602, 1604.

[30] Salles C., Herve C., Septier C., Demaizieres D., Lesschaeve I., Issanchou S., Le Quéré J.L., Evaluation of taste compounds in watersoluble extract of goat cheese, Food Chem. 68 (2000) 429-435.

[31] Salles C., Sommerer N., Septier C., Issanchou S., Chabanet C., Garem A., Le Quéré J.L., Goat cheese flavor: Sensory evaluation of branched-chain fatty acids and small peptides, J. Food Sci. 67 (2002) 835-841. 